DOI 10.15290/cnisk.2018.01.04.09

DR HAB. GRZEGORZ ZACKIEWICZ

orcid.org/0000-0001-9726-7163

Uniwersytet w Białymstoku

\title{
Maria Weber, Józefa Lis-Błońska. Ucieczka z twierdzy „Bobrujsk”, Warszawa : Oficyna Wydawnicza Rytm, 2016, ss. 152, ISBN 978-83-7399-703-5
}

Maria Weber, autorka recenzowanej książki, jest absolwentką geografii Uniwersytetu Warszawskiego. Na tej samej uczelni ukończyła też dziennikarstwo. Przez wiele lat była związana zawodowo $z$ Polskim Radiem. Współpracowała także m.in. z dziennikiem „Rzeczpospolita”, zajmując się problematyka społeczno-gospodarcza. Od pewnego czasu, m.in. jako publicystka magazynu „Focus Historia”, wykazuje duże zainteresowanie tematyką historyczną, ze szczególnym uwzględnieniem roli kobiet w walce o niepodległość Polski w XX w. Nie będąc profesjonalnym historykiem, niedawno opublikowała biografie Emilii Malessy oraz Władysławy Macieszyny ${ }^{1}$. Najnowsza książka autorstwa Weber, zatytułowana Józefa Lis-Błońska. Ucieczka z twierdzy „Bobrujsk”, wpisuje się w ten właśnie nurt jej zainteresowań.

Bohaterka wydanej w 2016 r. pracy była niewatpliwie osobą nietuzinkową, zasłużona w walce o niepodległość, przez kilkadziesiąt lat dorosłego życia zaangażowaną w wiele ważnych inicjatyw społecznych i politycznych. Trudno wszak zaprzeczyć, że pozostawała na uboczu kluczowych wydarzeń w skali ogólnopolskiej. Stąd też próbę napisania jej całościowej biografii należy uznać za zadanie karkołomne. Z góry można

1 M. Weber, Emilia Malessa „Marcysia” 1909-1949. Wybawieniem jest śmierć, Warszawa 2013; Eadem, Agentka dwóch wojen. Władysława Macieszyna „Sława” 1888-1967, Warszawa 2014. 
było bowiem założyć, że pewnych faktów z życiorysu Józefy Lis-Błońskiej nie uda się autorce ustalić.

Przygotowując wspomniana wyżej publikację, Weber przeprowadziła dość gruntowną kwerendę archiwalną i biblioteczną. Sięgnęła m.in. do materiałów przechowywanych w Archiwum Akt Nowych w Warszawie, prowadziła poszukiwania w Bibliotece Narodowej oraz w Centralnym Archiwum Wojskowym. Korzystała też z zasobów Instytutu Pamięci Narodowej i warszawskiego Ośrodka Karta. Niebagatelne znaczenie dla ostatecznego kształtu książki miał fakt, iż autorce udało się dotrzeć do kilku archiwów prywatnych i w ten sposób uzyskać wiele informacji na temat losów Lis-Błońskiej.

Konstrukcja książi jest nietypowa, jeśli wziąc za punkt odniesienia klasyczne biografie pisane przez profesjonalnych historyków. Rozdział pierwszy, utrzymany raczej w konwencji reportażu niż pracy naukowej, opowiada o dramatycznych losach Lis-Błońskiej i jej rodziny we wrześniu i październiku 1939 r., gdy nad Wisłą rozpadał się świat dotychczasowych wartości i wyobrażeń. Można się zastanawiać, czy inspiracja dla autorki nie była w tym przypadku znana powieść Marii Dabrowskiej Noce $i$ dnie. Także w kolejnych fragmentach recenzowanej ksiażki - tu już zastosowany został schemat oparty na chronologii - łatwo dostrzec, że Weber nie ma wykształcenia historycznego. Publikacja jest wprawdzie opatrzona przypisami (których konstrukcja pozostawia jednak wiele do życzenia i nie odpowiada standardom wymaganym w pracach o ambicjach naukowych) i ma bibliografię, niemniej nosi wyraźne piętno opracowania, którego autorka wykorzystała przede wszystkim bogate doświadczenie zawodowe $z$ pracy dziennikarskiej. Ksiażka została napisana bardzo dobra polszczyzna, a narracje poprowadzono w taki sposób, że lektura od pierwszej do ostatniej strony jest zajmująca.

Tytułowa bohaterka urodziła się prawdopodobnie w 1902 r. jako Józefa Maria Michałowska. Pochodziła $z$ relatywnie dobrze sytuowanej rodziny $z$ okolic Mińska². W tym mieście ukończyła gimnazjum. Ziunia - jak ja zdrobniale określano - była naocznym świadkiem burzliwych wydarzeń przełomowej epoki, gdy najpierw upadł carat, a później Mińsk wraz z okolicznymi miejscowościami kilkakrotnie doświadczał przemar-

2 Jak ujęła to Weber, ojciec Józefy „Konstanty Michałowski miał smykałkę do interesów” (zob. M. Weber, Józefa Lis-Błońska. Ucieczka z twierdzy „Bobrujsk”, Warszawa 2016, s. 30). 
szów różnych wojsk i zbrojnych band. $Z$ punktu widzenia nastoletniej Polki jednym $z$ najbardziej traumatycznych przeżyć tego czasu był napad na wiejska posiadłość Michałowskich w Łoszycach. Bohaterka książki bardzo wcześnie miała okazję zetknąć się z praktyką bolszewicką i wyrobić sobie pogląd na temat komunizmu.

W tym okresie Michałowska, zaangażowana w działalność żeńskiej drużyny harcerskiej im. Emilii Plater, znalazła się w kręgu oddziaływania Polskiej Organizacji Wojskowej (POW). Do tej konspiracyjnej organizacji wstapiła w lutym 1919 r. We wspomnieniowej relacji - cytowanej także przez Weber - pisała m.in.:

P.O.W. na Białej Rusi zaczęła realnie działać w końcu 1918 r. po opuszczeniu ziemi białoruskiej przez Niemców i zajęciu jej przez bolszewików. (...) W tym to okresie powstał Oddział Żeński P.O.W., w przeważnej ilości składający się $z$ miejscowych skautek, uczennic ostatnich 2 klas istniejących w Mińsku szkół polskich (...). Któż by podejrzewał młode dziewczęta, uczennice, tak pilnie $z$ pozoru zajęte nauką ${ }^{3}$.

Michałowska, która początkowo przenosiła bibułe, rewolwery i paczki nabojów, rozkazy do członków organizacji, ubrania dla zbiegłych polskich żołnierzy (s. 46), stopniowo zaczęła odgrywać coraz większą rolę w mińskich strukturach POW. W późniejszym okresie do jej obowiazków należało przepisywanie rozkazów i raportów Komendantury Naczelnej POW na Białorusi. Jak określono to we wniosku o jej odznaczenie, Michałowska pracowała w najcięższych warunkach wzmożonej czujności czerezwyczajek, (...) stale narażając się na niechybna śmierć (s. 73). W czasie wojny polsko-bolszewickiej uczestniczyła w ryzykownych działaniach mających na celu wydostanie $z$ twierdzy w Bobrujsku komendanta POW na Białorusi Mateusza Stefanowskiego. Jakkolwiek próba nie zakończyła się powodzeniem, Michałowska została doceniona. W wolnej Polsce w 1922 r. odznaczono ja Orderem Wojennym Virtuti Militari V Klasy.

W pierwszych latach II RP bohaterka ksiażki pracowała jako tłumaczka oraz referentka w Oddziale II Dowództwa Frontu Litewsko-Białoruskiego i w Oddziale II Sztabu Generalnego Wojska Polskiego. Jeszcze

3 J. Michałowska, Z pracy P.O.W. w Mińsku Litewskim [w:] Służba Ojczyźnie. Wspomnienia uczestniczek walk o niepodległość 1915-1918, red. M. Rychterówna, Warszawa 1929, s. $340,344$. 
w Mińsku poznała swojego późniejszego męża, por. Stanisława Lis-Błońskiego, za którego wyszła latem 1923 r. Niecały rok później małżonkowie doczekali się jedynej córki, której nadali imię Danuta. W tym czasie mieszkali już w Warszawie.

Począwszy od 1924 r., Lis-Błońska zrezygnowała ze stałej pracy zawodowej. Wychowując dziecko - mąż był wojskowym o niemałych ambicjach politycznych - konsekwentnie angażowała się jednak w różnego rodzaju inicjatywy społeczne. Profil ideowy tych przedsięwzięć skłania do tego, by Lis-Błońską zaliczyć do kręgu zwolenników niepodległościowej lewicy, a ściślej rzecz biorąc, dostrzec w niej przedstawicielkę środowiska, które nie wyrzekając się społecznego radykalizmu, sympatyzowało z Józefem Piłsudskim ${ }^{4}$. Bohaterka książki należała m.in. do współzałożycielek stowarzyszenia „Rodzina Wojskowa”, działała na forum Związku Pracy Obywatelskiej Kobiet, uczestniczyła w pracach Zwiazku Peowiaków. Tuż przed wybuchem wojny opublikowała powieść zatytułowana Ludzie $z$ rozstajnych dróg. Ważnym polem jej aktywności było również dziennikarstwo. Należy tu wymienić współpracę $z$ takimi pismami jak „Kobieta Współczesna” i „Bluszcz”. Stwierdzenie, że Lis-Błońska „walczyła o sprawy kobiet piórem", Weber opatrzyła następujacym komentarzem: Czy była feministka?? Nie wydaje się. Chciała jedynie uwolnić kobiety z niewidzialnego gorsetu ograniczen, których one same broniły (s. 91).

Czytając fragmenty książki odnoszące się do lat 1924-1939, można dojść do przekonania, że intencja autorki było przedstawienie Lis-Błońskiej jako kobiety silnej i samodzielnej, aktywnej i zaangażowanej na polu różnego rodzaju działań społecznych, zarazem jednak nie do końca spełnionej w małżeństwie i niezależnie od relatywnie wysokiego statusu materialnego, poddanej ciężkim doświadczeniom osobistym. Szczególnie traumatycznym przeżyciem okazała się tu samobójcza śmierć ojca. W istocie jednak najgorsze dla Lis-Błońskiej miało dopiero nadejść wraz z wybuchem II wojny światowej.

\footnotetext{
4 Zdaniem Weber Józefie Lis-Błońskiej najbliżej było do „idei Polskiej Partii Socjalistycznej" (zob. M. Weber, Józefa Lis-Błońska..., op. cit., s. 9). Teza ta wydaje się cokolwiek kontrowersyjna, nie tylko biorąc pod uwagę ewolucję stanowiska PPS wobec Piłsudskiego po 1926 r. Bardziej przekonująca byłaby chyba konstatacja, że Lis-Błońska szukała dla siebie miejsca w obrębie lewicy sanacyjnej. Takie ujęcie problemu poniekąd tłumaczyłoby także późniejsze zwiazki bohaterki książki z syndykalistyczną konspiracją w czasie II wojny światowej.
} 
Fragmenty dotyczące losów tytułowej bohaterki książki po 1939 r. wydają się szczególnie wstrząsające. Strata męża już w pierwszych tygodniach wojny, a następnie córki (Danuta Lis-Błońska zginęła w powstaniu warszawskim) stanowiły dla dzielnej niewattpliwie kobiety niewyobrażalna, osobistą tragedię. Pomimo to Lis-Błońska $z$ wielkim poświęceniem działała w szeregach ruchu oporu. Należała do Związku Syndykalistów Polskich (ZSP), niewielkiej, radykalnej społecznie organizacji niepodległościowej, której liderzy wywodzili się ze środowiska lewicy piłsudczykowskiej. Zaangażowana równocześnie w prace „Żegoty”, przez kilkanaście miesięcy ukrywała we własnym mieszkaniu młoda Żydówkę. W czasie powstania warszawskiego, nie mając możliwości dotarcia do towarzyszy broni z ZSP, zgłosiła się do punktu sanitarnego w Śródmieściu (s. 114).

Po wojnie Lis-Błońska podjęła pracę w Polskim Radiu. Na antenie wielokrotnie przypominała sylwetki poległych towarzyszy broni $z$ lat II wojny światowej. Negatywnie oceniając bieg wydarzeń w powojennej Polsce i mając świadomość, że radio staje się tuba propagandowa władzy komunistycznej, przeżywała zarazem dramatyczne rozterki zwiazane $z$ podjęciem decyzji o pracy na rzecz „reżimu okupanta”. Całości obrazu dopełniała - sugestywnie opisana przez Weber - toksyczna, ewidentnie niszcząca dla ciężko doświadczonej w czasie okupacji kobiety relacja uczuciowa Lis-Błońskiej ze Stefanem Szwedowskim, wojennym przywódca ZSP, według autorki nawiąana prawdopodobnie pod koniec $1942 \mathrm{r}$.

O dalszych losach Lis-Błońskiej czytelnik książki dowie się stosunkowo niewiele. Jak ustaliła Weber, tytułowa bohaterka została zwolniona z pracy w 1949 r. ${ }^{5}$ Po odejściu z Polskiego Radia zatrudniła się w redakcji miesięcznika „Teatr Ludowy”. Później była m.in. związana z pismem „Praca Świetlicowa”, by w końcu objąć stanowisko korektorki w Państwowym Wydawnictwie Naukowym. Na emeryturę przeszła w 1963 r. Przez wiele lat - głównie chyba jednak z racji zwiąku ze Szwedowskim, który pozostawał w kręgu zainteresowania komunistycznych służb aż do swojej śmierci w 1973 r. ${ }^{6}$ - była inwigilowana przez „bezpiekę". Obszernie cytowane przez Weber fragmenty agenturalnych donosów $z$ lat 1951-1965, abstrahując od ich wartości informacyjnej, robia przy

\footnotetext{
5 Jak ujęła to Weber, Lis-Błońska „nie chciała firmować kłamstwa”: „Toteż, zwłaszcza po 1948 roku, zaczęły się konflikty, nagany $z$ wpisaniem do akt, upomnienia, ograniczanie tematyki i czasu antenowego" (M. Weber, Józefa Lis-Błońska..., op. cit., s. 127).

6 G. Zackiewicz, Syndykalizm w polskiej refleksji i rzeczywistości politycznej I połowy XX wieku, Kraków 2013, s. 707-709.
} 
tym przygnębiające wrażenie. Zabieg polegający na ograniczeniu autorskiego komentarza, co można też jednak odebrać jako swego rodzaju unik, niewątpliwie spotęgował wspomniany efekt.

Józefa Lis-Błońska - oceniła Weber - jest reprezentantka pokolenia, które musiało dwukrotnie walczyć o niepodległość. Różne były losy i postawy ludzi, którzy przeżyli wojnę. Ona akurat znalazła się w gronie ludzi niezłomnych (s. 9).

Nie kwestionując oczywistych zasług, niebywałej determinacji, wielokrotnie demonstrowanego hartu ducha i osobistej odwagi, można jednak zaryzykować tezę, że wraz z upływem czasu tytułowa bohaterka co skądinąd nietrudne do zrozumienia w świetle jej osobistych doświadczeń - stopniowo rewidowała swoje wcześniejsze nastawienie, godząc się $z$ nieuchronnością rządów komunistycznych w Polsce. W wykorzystywanym także przez Weber pamiętniku Lis-Błońska pod datą 21 lipca 1945 r. zapisała: Ja nie wierze $w$ zmiane na lepsze. Za mego życia ta zmiana nie nastapi ${ }^{7}$. Niedługo potem, w listopadzie tego roku, być może pod wpływem pobytu na Ziemiach Zachodnich, napisała o komunistach: Czasami myślę: a może oni kochaja Polskę, chca $z$ niej zrobić państwo postępowe, nowoczesne i tak się poświęcaja kosztem swojej popularności. A że koniunktura jest na Rosję, musza sie jej wysługiwać ${ }^{8}$. Warto zauważyć, o czym zreszta jest mowa w książce, że Lis-Błońska zgłosiła chęć przystapienia do Związku Bojowników o Wolność i Demokrację.

Kres życia Lis-Błońskiej nastapił jesienia 1970 r. Tytułowa bohaterka książki zmarła na zawał serca. Być może - jak zasugerowała Weber - wpływ na okoliczności śmierci miała odbyta niedługo przedtem rozmowa telefoniczna $z$ byłym już wówczas mężem Szwedowskim.

Reasumując, należy stwierdzić, że recenzowana książka nie jest typową biografią historyczną. Jak się wydaje, takie też było zamierzenie autorki, która nie pretenduje przecież do miana profesjonalnego historyka. Trudno zatem oceniać niniejsza publikację przy zastosowaniu kryteriów stosowanych w przypadku klasycznych opracowań naukowych. Natomiast jako praca popularnonaukowa, napisana przy wykorzystaniu warsztatu dziennikarskiego, gdzie zastosowano elementy reportażu,

\footnotetext{
7 Biblioteka Zakładu im. Ossolińskich we Wrocławiu, sygn. 14458/II, Józefa Lis-Błońska, Pamiętnik z lat 1939-1946, s. 242.

8 Ibidem, s. 243.
} 
książka broni się całkiem dobrze. Została starannie wydana, opatrzona licznymi zdjęciami i solidnie udokumentowana. Niewatpliwą zaletę opracowania stanowi sugestywny styl autorki. Książkę autorstwa Weber można bez większych zastrzeżeń uznać za interesująca.

Tło historyczne opisywanych wydarzeń z życia Lis-Błońskiej zostało przedstawione w sposób poprawny, choć w niektórych miejscach albo zbyt pobieżnie, albo też - jak choćby w przypadku dziejów I Korpusu Polskiego gen. Józefa Dowbór-Muśnickiego - z niepotrzebnymi odniesieniami do kwestii o drugorzędnym w tym wypadku znaczeniu. Autorka - co raz jeszcze warto podkreślić, niebędąca zawodowym historykiem - ustrzegła się popełnienia dużej ilości rażących błędów. Nie znaczy to bynajmniej, że ze wszystkimi stwierdzeniami Weber można się zgodzić. Gwoli recenzenckiego obowiązku należy wytknąć autorce choćby sformułowanie, że Władysław Raczkiewicz był podczas II wojny światowej prezydentem rzadu polskiego na uchodźstwie (s. 33). Razi też, z pozoru efektownie brzmiace stwierdzenie, że poczatki osadnictwa wojskowego w II RP przypominały kolonizację Dzikiego Zachodu (s. 79). Z kolei konkluzja, że syndykaliści widzieli Polske powojenna jako państwo antydemokratyczne, bo pozbawione parlamentaryzmu (s. 103), wydaje się wynikać $z$ nader uproszczonego, a przez to fałszywego interpretowania przez autorkę założeń politycznych ZSP $^{9}$. Niezrozumiała jest sugestia Weber, jakoby syndykaliści na Zachodzie marzyli o „silnym przywódcy”, który stanie na czele państwa zbudowanego w oparciu o zwiazki zawodowe (s. 104).

Wartość recenzowanej książki polega niewatpliwie na tym, że przypomniana została zasłużona, a dotąd praktycznie nieznana postać Józefy Lis-Błońskiej. Była to osoba $z$ wielu względów niezwykła, której losy są dobitnym potwierdzeniem, jak ważną rolę na drugim planie wielkich wydarzeń historycznych odgrywały anonimowe zazwyczaj z dzisiejszej perspektywy Polki. O tym wszystkim Maria Weber napisała w sposób bardzo sugestywny, przekonujący, $z$ dużą sympatią dla bohaterki swej opowieści. Trudno zatem kwestionować pogląd, że recenzowana publikacja może służyć popularyzacji historii najnowszej, budzić zainteresowanie przeszłościa, a zwłaszcza kwestia roli kobiet w przełomowych

9 Na temat myśli politycznej ZSP: S. Ciesielski, Koncepcje polityczne Zwiazku Syndykalistów Polskich w latach drugiej wojny światowej, „Acta Universitatis Wratislaviensis. Historia" 1992, t. 40, s. 253-284. 
wydarzeniach ostatniego stulecia na naszych ziemiach. $Z$ punktu widzenia profesjonalistów zajmujących się historia użyteczność recenzowanej publikacji jest już jednak bez wątpienia dużo mniejsza, a mankamenty książki nietrudne do wychwycenia.

\section{Bibliografia}

\section{Źródła}

Biblioteka Zakładu im. Ossolińskich we Wrocławiu, sygn. 14458/II, Józefa Lis-Błońska, Pamiętnik $z$ lat 1939-1946.

Michałowska Józefa, Z pracy P.O.W. w Mińsku Litewskim [w:] Służba Ojczyźnie. Wspomnienia uczestniczek walk o niepodległość 1915-1918, red. Maria Rychterówna, Warszawa : Główna Księgarnia Wojskowa, 1929.

\section{Opracowania}

Ciesielski Stanisław, Koncepcje polityczne Zwiazku Syndykalistów Polskich $w$ latach drugiej wojny światowej, „Acta Universitatis Wratislaviensis. Historia" 1992, t. 40, s. 253-284, ISSN 0524-4498.

Weber Maria, Agentka dwóch wojen. Władysława Macieszyna „Stawa” 1888-1967, Warszawa : Oficyna Wydawnicza Rytm, 2014, ISBN 97883-7399-618-2.

Weber Maria, Emilia Malessa „Marcysia” 1909-1949. Wybawieniem jest śmierć, Warszawa : Oficyna Wydawnicza Rytm, 2013, ISBN 978-837399-571-0.

Zackiewicz Grzegorz, Syndykalizm w polskiej refleksji i rzeczywistości politycznej I połowy XX wieku, Kraków : Avalon, 2013, ISBN 978-83-7730088-6. 